\title{
The effects of lead and nickel ions on total proteins and metallothioneins synthesis in mice liver
}

\author{
Indrè Šveikauskait $\dot{e}^{1 *}$, \\ Jurgita Šulinskiené2, \\ Ilona Sadauskiené², \\ Leonid Ivanov ${ }^{2}$ \\ ${ }^{1}$ Pharmacy Faculty, \\ Eiveniu str. 4, \\ Kaunas, Lithuania \\ ${ }^{2}$ Neuroscience Institute, \\ Lithuanian University \\ of Health Sciences, \\ Eiveniu str. 4, \\ Kaunas, Lithuania
}

The present study was conducted to investigate the effects of lead and nickel ions on total proteins and metallothioneins synthesis in mice liver. Lead $(\mathrm{Pb})$ is a heavy metal used in a wide variety of consumer products and occupational settings. Nickel (Ni) is a ubiquitous metal element found in a wide variety of compounds. The protein synthesis is the process by which biological cells generate new proteins. Metallothioneins (MTs) are a group of small proteins found in the cytosol of cells, particularly of liver, kidney, and intestine. Experiments were done on 4-6 weeks old white laboratory outbreed mice weighing 20-25 g. Concentration of protein was determined by Lowry method. MTs were assayed in mice liver according to Peixoto method. There are no statistically significant changes in lead group after 14 days experiment. After 14 days of injections of $\mathrm{NiCl}_{2}$ solution, marked amino acid actuation to new synthesized protein has increased by $57 \%$, in mice liver treated with $\mathrm{Pb}\left(\mathrm{CH}_{3} \mathrm{COO}\right)_{2}$ MTs content was increased by $57 \%$ compared with control. In mice liver treated with $\mathrm{NiCl}_{2} \mathrm{MTs}$ content was increased by $55 \%$ compared with control. There is no statistically significant effect of lead on protein synthesis in mice liver. According to the data, injections of $\mathrm{NiCl}_{2}$ solution marked amino acid actuation to new synthesized proteins has increased. The obtained data showed that in mice liver treated with $\mathrm{NiCl}_{2}$ and $\mathrm{Pb}\left(\mathrm{CH}_{3} \mathrm{COO}\right)_{2}$ solutions MTs content was increased.

Key words: lead, nickel, protein synthesis, metallothioneins synthesis

\section{INTRODUCTION}

Lead $(\mathrm{Pb})$ is a heavy metal used in a wide variety of consumer products and occupational settings (Dart, 2000). Lead reaches liver through the

*Corresponding author. E-mail: indresvei@gmail.com intestine and portal vein. One lead part stands out through liver with bile, the other part accumulates in hepatocytes (Ptašekas et al., 2002). Lead inhibits both ALA dehydratase and ferrochelatase, thereby reducing heme synthesis and resulting in microcytic, hypochromic anemia. 
Plasma ALA and erythrocyte protoporphyrin concentrations are increased in people with lead poisoning. Furthermore, since heme is the prosthetic group of many enzymes and proteins, including the cytochromes of the mitochondrial electron-transport chain, lead poisoning can also have detrimental effects on energy metabolism. Lead is especially toxic to the nervous system, probably due to accumulation of $\delta$-aminolevulinic acid as well as to impaired energy metabolism (Rosenthal et al., 2009).

Nickel (Ni) is a ubiquitous metal element found in a wide variety of compounds. Exposures of clinical significance involve pulmonary complications of inhalation of nickel alloys in welders, leading to asthma, fibrosis, and pulmonary edema. Nickel crosses placenta and gets into breast milk (Dart et al., 2000). Nickel is not considered an essential element for human health and dietary recommendations for nickel have not been established. Depending on the form, nickel can enter the body through the skin, lungs, and gastrointestinal tract. Following inhalational exposure, nickel tends to accumulate in the lungs, and only 20$35 \%$ of nickel deposited in the human lungs is absorbed. Soluble nickel salts are more easily absorbed, whereas less soluble oxides and sulfides of nickel have much lower levels of absorption (Hoffmal et al., 2007).

The protein synthesis is the process by which biological cells generate new proteins. Protein synthesis is divided into three stages: initiation, elongation and termination (Lieberman et al., 2007). Initiation involves formation of a complex containing the initial methionyl-tRNA bound to the AUG "start" codon of the mRNA and to the "P" site of the ribosome. It requires guanosine triphosphate (GTP) and proteins known as eukaryotic initiation factors. Elongation of the polypeptide involves three steps: 1 ) binding of an aminoacyl-tRNA; 2) formation of a peptide bond between the first and second amino acids and 3) translocation, movement of the mRNA relative to the ribosome, so that the third mRNA codon moves into the "A" site. These three elongation steps are repeated until a termination codon aligns with the site on the ribosome where the next aminoacyl-tRNA would normally bind. Release factors bind instead causing the completed protein to be released from the ribosome (Lieberman et al., 2013).

When liver protein synthesis is compromised, the protein levels in the blood are reduced. Hypoproteinemia may lead to edema because of a decrease in the protein-mediated osmotic pressure in the blood. This, in turn, causes plasma water to leave the circulation and enter (and expand) the interstitial space causing edema. Most circulating plasma proteins are synthesized by the liver (Lieberman et al., 2013).

Metallothioneins (MTs) are a group of small proteins (about $6.5 \mathrm{kDa}$ ) found in the cytosol of cells, particularly of liver, kidney, and intestine (Bender et al., 2009). Metallothioneins bind to heavy metals, many of which are toxic for metabolic processes and sequester them. The synthesis of this protective protein by the liver is induced by heavy-metal ions such as cadmium (Berg et al., 2007). The SH groups of cysteine are involved in binding the metals. Acute intake (e. g. by injection) of copper and of certain other metal increases the amount (induction) of these proteins in tissues, as does administration of certain hormones or cytokines. These proteins may function to store the above metals in a nontoxic form and are involved in their overall metabolism in the body. Sequestration of copper also diminishes the amount of this metal available to generate free radicals (Bender et al., 2009).

The present study was conducted to investigate the effects of lead and nickel ions on total proteins and metallothioneins synthesis in mice liver.

\section{MATERIALS AND METHODS}

Subject of research. Experiments were done on 4-6 weeks old white laboratory outbreed mice weighing $20-25 \mathrm{~g}$. All experiments were performed according to Law on the Care, Keeping and Use of Animals of the Republic of Lithuania (License of State Veterinary Service for working with laboratory animals No 0200). 
Mice were randomly assigned into three groups: two experimental and one control. Each group included 8-12 mice. Mice were intraperitoneally (i. p.) injected for 14 days (once a day) with metal salts solutions. Mice of the first experimental group were injected with $\mathrm{Pb}\left(\mathrm{CH}_{3} \mathrm{COO}\right)_{2}$ solution in deionised water $\left(0.1 \mathrm{LD}_{50} ; 10 \mathrm{mg} \mathrm{Pb}\right.$ per kg of body mass). Mice of the second experimental group received intraperitoneal injection of $\mathrm{NiCl}_{2}\left(0.1 \mathrm{LD}_{50}\right.$; $1.12 \mathrm{mg} \mathrm{Ni}$ per $\mathrm{kg}$ of body mass). Control animals (the third group) received an injection of the same volume of saline.

Measurement of protein synthesis. For measurement of protein synthesis [14C]-labelled arginine was injected i. p. $1 \mathrm{~h}$ before killing. Intensity of the protein synthesis in mice liver was evaluated by the incorporation of [14C]arginine into newly synthesized proteins and peptides. Arg was selected as an amino acid tag because of its prevalence in cellular proteins of the liver. Concentration of protein was determined by Lowry method.

MTs content assay in mice liver. MTs were assayed in mice liver according to the method of Peixoto N. C. To the aliquots of $1 \mathrm{ml}$ of supernatant were added $1.05 \mathrm{ml}$ of cold $\left(-20^{\circ} \mathrm{C}\right)$ absolute ethanol and $80 \mu$ of chloroform; then the samples were centrifuged at $6000 \times \mathrm{g}$ for $10 \mathrm{~min}$. The collected supernatant was combined with 3 volumes of cold ethanol $\left(-20^{\circ} \mathrm{C}\right)$, kept at $-20^{\circ} \mathrm{C}$ for $1 \mathrm{~h}$ and centrifuged at $6000 \times \mathrm{g}$ for
$10 \mathrm{~min}$. The MTs containing pellets were then rinsed with $87 \%$ ethanol and $1 \%$ chloroform and centrifuged at $6000 \times \mathrm{g}$ for $10 \mathrm{~min}$. The MTs content in the pellet was evaluated using the colorimetric method with Ellman's reagent. The pellet was resuspendent in $150 \mu \mathrm{l} 0.25 \mathrm{M}$ $\mathrm{NaCl}$ and subsequently $150 \mu \mathrm{l} \mathrm{N} \mathrm{HCl}$ containing $4 \mathrm{mM}$ ethylenediaminetetraacetic acid was added to the sample. A volume of $4.2 \mathrm{ml}$ $2 \mathrm{M} \mathrm{NaCl}$ containing $0.43 \mathrm{mM}$ 5.5'-dithiobis(2-nitrobenzoic acid) buffered with $0.2 \mathrm{M}$ Na-phosphate, $\mathrm{pH} 8.0$ was then added to the sample at room temperature. The sample was finally centrifuged at $3000 \times \mathrm{g}$ for $5 \mathrm{~min}$; the supernatant absorbance was evaluated at wave $412 \mathrm{~nm}$ and MTs concentration was expressed as $\mu \mathrm{g} / \mathrm{g}$ of wet weight of kidney.

Statistical analysis. Results were expressed as the mean \pm standard error of mean. Statistical significance was set at $\mathrm{p}<0.05$.

\section{RESULTS}

The effects of lead and nickel ions on total protein synthesis in mice liver in vivo

In many scientific sources it is indicated that lead could suppress or activate protein synthesis, these processes are depended upon dose and effect time. According to data presented in Fig. 1, there are no statistically significant changes in lead group after 14-day experiment. This result could be related with

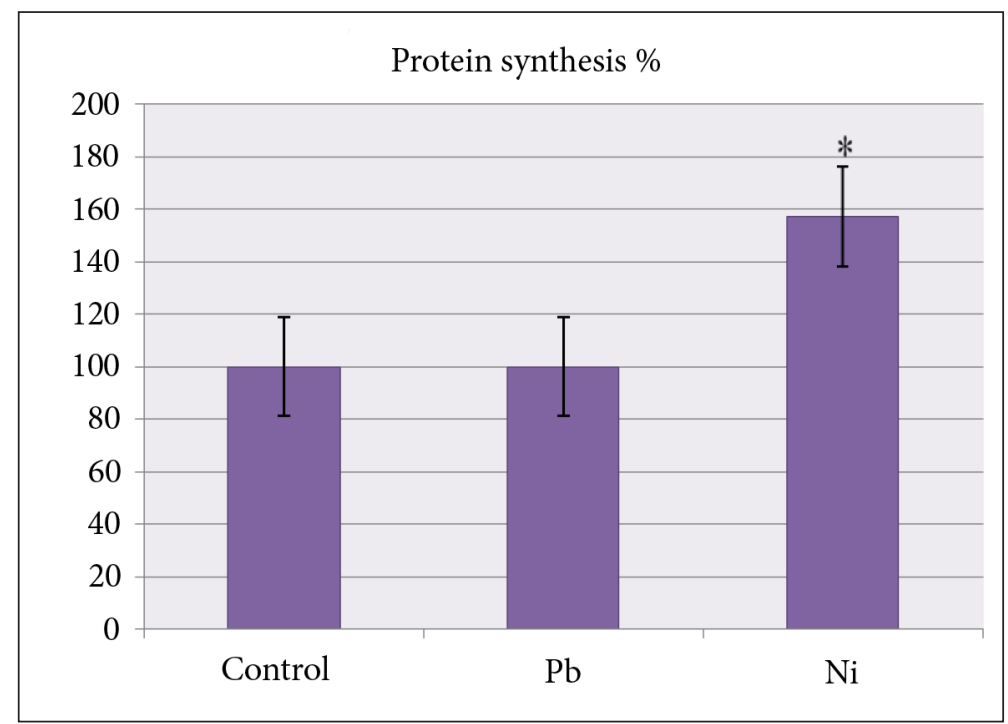

Fig. 1. Protein synthesis on mice liver after 14 days of exposure $10 \mathrm{mg} / \mathrm{kg}$ of $\mathrm{Pb}^{2+}$ and $1.12 \mathrm{mg} / \mathrm{kg}$ of $\mathrm{Ni}^{2+}{ }^{*}-\mathrm{p}<0.05$ as compared to the control mice. Data represent results of 8-12 separate experiments 
Fig. 2. Hepatic concentration of MTs of mice after 14 days of exposure $10 \mathrm{mg} / \mathrm{kg}$ of $\mathrm{Pb}^{2+}$ and $1.12 \mathrm{mg} / \mathrm{kg}$ of $\mathrm{Ni}^{2+} .{ }^{*}-\mathrm{p}<0.05$ as compared to the control mice. Data represent results of $8-12$ separate experiments

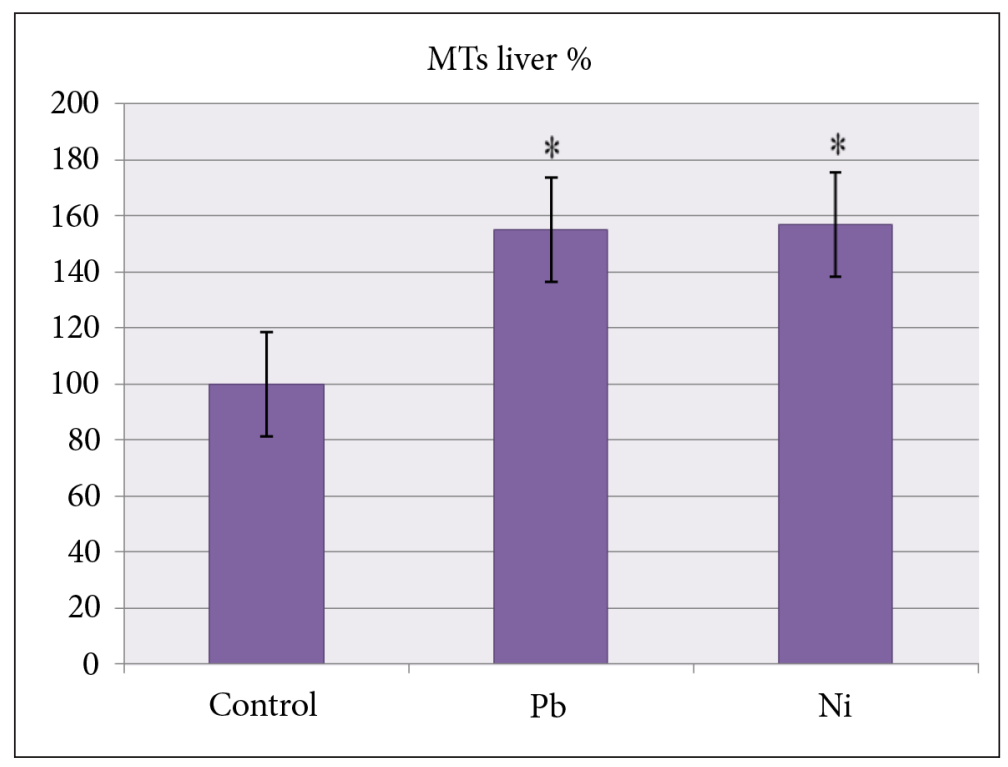

the mechanism of adaptation against toxic lead effect (Kasperczyk et al., 2004).

After 14 days of injections of $\mathrm{NiCl}_{2}$ solution, marked amino acid actuation to new synthesized protein has increased by $57 \%(\mathrm{p}<0.05)$ as compared with control. This result could be related with increased (57\%) metallothioneins and other protective protein syntheses after 14 days. Nickel activates metallothioneins synthesis.

Summarizing, the effets of lead and nickel on total protein synthesis in mice liver in vivo showed that the effects are due to both metals exposure time and the amount of them accumulated in mice body.

The effects of lead and nickel ions on the content of metallothioneins in mice liver

The obtained data showed that in mice liver treated with $\mathrm{Pb}\left(\mathrm{CH}_{3} \mathrm{COO}\right)_{2}$ MTs content was increased by $57 \%$ as compared with control (Fig. 2). This result shows that lead could induce MTs synthesis. In literature lead is named as undirect MTs inductor because lead activates MTs only in vivo, but not in vitro (Park et al., 2001). After 14 days $\mathrm{Pb}\left(\mathrm{CH}_{3} \mathrm{COO}\right)_{2}$ effect, MTs synthesis increases to $157 \%$ could be related with huge amount of lead in cell.

In mice liver treated with $\mathrm{NiCl}_{2}$ MTs content increased by $55 \%$ compared with control. Nickel activated MTs synthesis.

\section{CONCLUSIONS}

There is no statistically significant effect of lead on protein synthesis in mice liver. According to the data, after 14 days of injections of $\mathrm{NiCl}_{2}$ solution, marked amino acid actuation to new synthesized proteins has increased. The obtained data showed that in mice liver treated with $\mathrm{NiCl}_{2}$ and $\mathrm{Pb}\left(\mathrm{CH}_{3} \mathrm{COO}\right)_{2}$ solutions, MTs content increased.

Received 27 May 2013 Accepted 05 January 2014

\section{References}

1. Dart RC. The 5 minute toxicology consult. A Wolters Kluwer Company; 2000.

2. Ptašekas R, Ptašekas M. Švinas. Toksikogenezé, jos tyrimai. UAB Valbena, Vilnius; 2002.

3. Rosenthal MD, Glew RH. Medical biochemistry. Human metabolism in health and disease. Wiley; 2009.

4. Hoffmal N, Howland L, Flomenbaum G. Manual of toxicologic emergencies. The McGrawHill Companies; 2007.

5. Lieberman M, Marks AD, Smith C. Essentials of medical biochemistry. A clinical approach. Lippincott Williams \& Wilkins; 2007. 
6. Lieberman M, Marks AD. Basic medical biochemistry. Lippincott Williams \& Wilkins; 2013.

7. Bender DA, Botham KM, Kennelly PJ, Rodwell VW, Weil PA. Harper's illustrated biochemistry. The McGraw-Hill Companies; 2009.

8. Berg JM, Tymoczko JL, Stryer L. Biochemistry P. 155 / W. H. Freeman and Company, New York; 2007.

9. Kasperczyk S, Kasperczyk A, Ostalowska A, Dziwisz M, Birkner E. Biol Trace Elem Res Winter 2004; 102(1-3): 61-72.

10. Park JD, Liu Y, Klaassen CD. Toxicology 2001; 163(2-3): 93-100.

Indrè Šveikauskaitė, Jurgita Šulinskienė, Ilona Sadauskienè, Leonid Ivanov

\section{ŠVINO IR NIKELIO JONU POVEIKIS}

BALTYMŲ IR METALOTIONEINŲ SINTEZEI LABORATORINIŲ PELIŲ KEPENYSE

\section{Santrauka}

Aprašytas eksperimentas buvo atliktas norint įvertinti švino ir nikelio jonų poveiki baltymų ir metalotioneinų sintezei laboratorinių pelių kepenyse. Švinas - sunkusis metalas, plačiai naudojamas įvairiose pramonės šakose ir itin kenksmingas žmogui. Nikelis - daugelyje junginių randamas elementas, taip pat toksiškai veikiantis organizmą. Abu sunkieji metalai gali turèti ittakos baltymų sintezei - procesui, kurio metu biologinès ląstelès sintetina naujus baltymus. Sunkiųjų metalų poveiki gali susilpninti metalotioneinai - mažos molekulinès masès baltymai, gebantys surišti sunkiųjų metalų jonus.
Eksperimentas buvo atliktas su 4-6 savaičių laboratorinèmis pelèmis, sveriančiomis 20-25 gramus. Baltymų koncentracija buvo matuojama Lowry metodu, metalotioneinų - Peixoto metodu. Iš gautų rezultatų galima daryti išvadą, kad švinas neturi statistiškai reikšmingos įtakos baltymų sintezei, o nikelio jonai aktyvino bendrą baltymų sintezę kepenyse. Abu metalai didino metalotioneinų sintezę kepenyse.

Raktažodžiai: švinas, nikelis, baltymų sintezé, metalotioneinų sintezè 